\title{
Central Banks on the Cross Roads - The Case of Macedonia
}

\author{
Prof. Dr. Ljube Trpeski (Ss. Cyril and Methodius University, Macedonia) \\ Dr. Bogoljub Jankoski (National Bank, Macedonia) \\ Ph.D. Candidate Vesna Kondratenko (National Bank, Macedonia)
}

\begin{abstract}
We focus on the use of unconventional measures implemented during the financial crisis and their impact on operational efficiency and independence of the central banks, including the National bank of Republic of Macedonia (NBRM). Measuring the impact of the new policies on the independence and operational efficiency of the central banks, we try to assess their capacity to maintain the price stability as primary monetary policy objective. In the paper the following methods are used: quantitative method, comparative method, particularly in comparison of the level of operational efficiency and the independence of central banks, as well as econometric method applied in operational efficiency analysis of the selected group of countries (developed, developing countries and countries in transition). As the other central banks, NBRM face the challenge to preserve its role in maintaining price and financial stability and economic strength of the country, without jeopardizing its independence. During the crisis, in coordination with other economic policies, NBRM succeeded to maintain macroeconomic stability and contributed to the mitigation of internal and external economic shocks. Also, NBRM managed to keep very high level of its legal and factual independence, measured by the standard indicators. However, the achievement of these multiple goals, resulted in decrease in the level of its operational efficiency, as it was case with the other central banks analyzed in this paper. Main message is that central banks have to undertake coordinated measures to fulfill their goals but also to take some measures to improve optimal level of efficiency.
\end{abstract}

\section{Introduction}

The last three decades, we have witnessed a generalized reduction of inflation. This was a reflection of the commitment of central banks of the advanced and the developing countries to attain the price stability as a primary goal. The pledge to price stability was credible thanks to greater independence achieved by central banks, both de jure and often de facto, particularly from fiscal authorities, during those years. The legitimacy of monetary policies was strengthened by lower inflation.

With the escalation of the economic and financial crisis in 2008, many countries have faced with significant decline of the fiscal inflows in parallel with the increase of government expenditures, so in circumstances of growth of public debt, central banks had an active role in preventing the further spread of the crisis and creating conditions for stable and sustainable economic growth. In 2010, macroeconomic policies were faced with new challenges as the cost of financing of the government debt increased significantly, especially in the peripheral member states of the euro zone, which contributed to the unsustainability of their fiscal policies. In order to prevent further expansion of the crisis and to mitigate the negative effects of the recession, central banks have taken many measures. A number of central banks lowered short-term policy rates to their zero lower bound and kept on that extraordinary low level for a quite long time. In order to revive the credit activity and economic growth, central banks extended the range of acceptable collateral for monetary policy operations and reduced the reserve requirements ratios.

But the financial crisis urged central banks to implement wide range of unconventional measures which were an essential element of their new strategies. However, the pressures to overload monetary policy with many goals, even if the tasks are claimed to be temporary, may lead to disappointment and loss of credibility for central banks (Sanchez, 2013). The potential for further rising costs and declining benefits has huge impact on the independence of central banks, because only financially independent central bank may be de facto independent. Did the five years of extraordinary monetary easing and unconventional measures change the character and the nature of independence of the central banks? Is an evolution happening in this field? Central bank independence is traditionally understood as preventing political pressures on the monetary policy. This could be named as struggle against 'fiscal dominance'. But the crisis has shown that this is narrow understanding of the independence of the central bank. Expanded concept of central bank independence includes other categories: "financial dominance" and "expectations dominance". The struggle against "financial dominance" means preventing pressure and impacts that come from financial markets and the highly indebted parts of the private sector. On the other hand, the strong involvement in resolving problems arising from the crisis contributed to unrealistically perception that the central bank can do much more than its real power. In this sense, prolonged monetary policy accommodation is perceived as the only way to overcome the crisis.

During the crisis, the line dividing monetary and quasi fiscal actions of many central banks has been blurred, driven by very high public debt. Further risks are arising from difficulties in efficient implementation of institutional structures covering both monetary policy and macro prudential policy mandates, as well as in 
fulfilling the price stability mandate in the current international environment, which is characterized by extensions for quantitative easing and greater volatility of financial flows (Marek Belka, 2013). This issue is particularly pertinent for emerging volatility of emerging economies.

\section{Monetary Policy and Unconventional Measures}

"Extraordinary times call for extraordinary measures, and we have already gone beyond traditional policy measures," (Ben Bernanke 2009).

The financial crisis urged the central banks to go beyond the standard monetary policy measures. The subprime crisis and the collapse of Lehman caused some banks to hedge against adverse liquidity risk which led to increase of the overnight rates in interbank markets and to high segmentation of the money markets. In response, the central banks of the advanced economies, Fed, Bank of England, European central bank and Bank of Japan, adopted several unconventional policy measures which led to high expansion of their balance sheets (Figure 1).

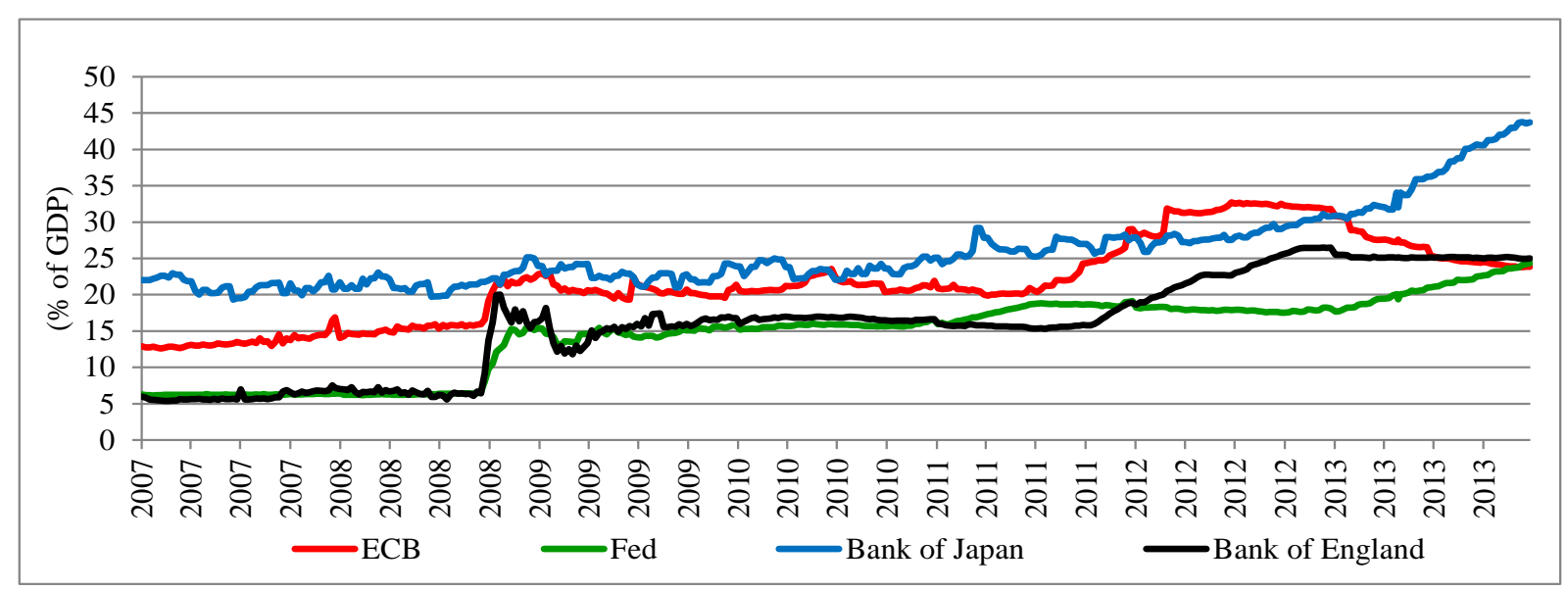

Figure 1. The total assets of the ECB, Fed, Bank of England and Bank of Japan

Unlike indirect impact on long-term interest rates which is usually conducted, during the recent financial and economic crisis, central banks started directly to affect the long term interest rates through unconventional measures of monetary policy as: i) credit easing by providing direct long term liquidity; ii) quantitative easing by purchasing long-term bonds and iii) forward guidance through providing information about future macroeconomic variables and stance of monetary policy. Therefore, when most central banks of advanced economies neared to zero lower bound, forward guidance was used to convince markets that the central bank will keep the rates on low level for longer period than consistent with its usual policy rule, which meant that they would allow inflation to go higher.

This policy measures had four objectives: first, to ease funding conditions for credit institutions and enterprises; second, to reduce money market term rates; third, to encourage credit institutions to maintain or expand their lending to households and enterprises; and, fourth, to improve market liquidity in important segments of private debt securities markets.

Finally, the accommodative monetary policy had to facilitate the process of restructuring the banks' and the private sector balance sheets, and to provide further implementation of structural reforms which are necessary preconditions for the revival of economic activity and strong and sustainable economic growth.

Generally, the implemented policies by the central banks in advanced economies were quite effective. The prolonged period of low interest rates and central bank asset purchases improved some indicators of bank soundness and revived the dis-functioned financial markets. In US, the liquidity in the securitized credit markets was restored and the market conditions were normalized. In euro area, the monetary policy measures prevented the huge bank deleveraging and credit contraction, as well as supported the decrease in bond yields in some euro area countries under market stress.

However, having in mind a lot of weaknesses in the financial systems, there are still risks of further contraction of credit and its effect on economic growth.

Macroeconomic indicators for the United States still do not provide a clear picture regarding the pace of recovery of the U.S. economy. Indicators showed growth of business confidence, but the data from the real sector do not yet indicate significant acceleration in economic activity. In such conditions, until more confident and more certain macroeconomic indicators are obtained, it is quite certain that the Fed will continue with its loose monetary policy and large scale asset purchases.

The reduced tensions in financial markets as well as loosening of fiscal consolidation allowed euro-zone to exit from recession, but the impediments on economic growth are only partially removed. Domestic demand is 
still weak and despite the decrease in yields on long-term bonds, the interest rates on loans are still high, so the volume of lending as a percentage of GDP continued to decline, particularly to non-financial corporations. The latest figures for the financial sector in the euro area suggest that the impaired assets are still high, profitability is low, and the loss absorption capacity is still too weak (ECB Financial Stability Review, November 2013).

\section{The Role of Monetary Policy of the NBRM}

NBRM applies monetary strategy of the exchange rate targeting. This means that the monetary policy is focused on maintaining low and stable inflation as the primary goal, while maintaining the stability of the nominal exchange rate of the denar against the euro, as an intermediate target. The changes in the monetary policy are usually response to the changes in the macroeconomic environment, which have a direct impact on the implementation of monetary targets. Thus, in circumstances where the stability of the nominal exchange rate is intermediate monetary target, the main point of interest of the monetary policy is the external position of the economy. The changes in the external position are mainly result from the private sector and government decisions and expectations, and from the external environment on the other side. They affect supply and demand on the foreign exchange market, and thus affect the stability of the exchange rate. In such conditions, the monetary policy of the NBRM has a proactive role in successful accomplishment of the defined monetary goals.

Maintaining the stability of the nominal exchange rate has proved as a crucial importance to the stability of prices and stable inflation expectations, so that in the period since 2004, inflation measured through the consumer price index, was around $2.5 \%$, on average (Figure 2). At the same time, the level of foreign exchange reserves constantly gravitated around the adequate level which expressed the capacity for surpassing the pressures on the exchange rate and provided high credibility of the monetary policy.

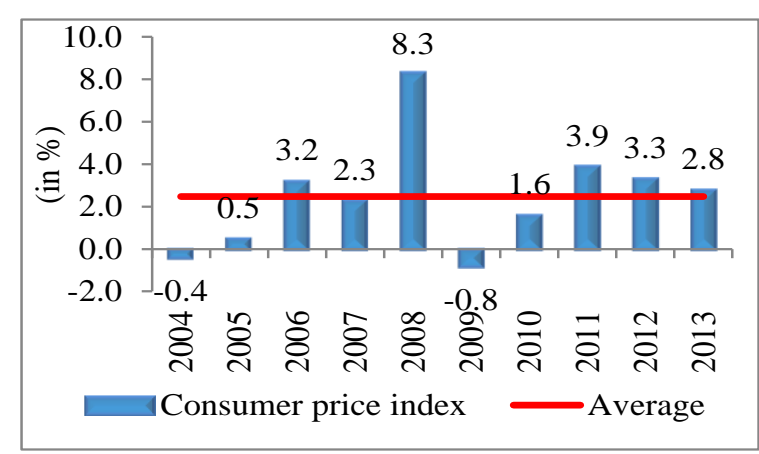

Figure 2. Consumer price index Source: NBRM

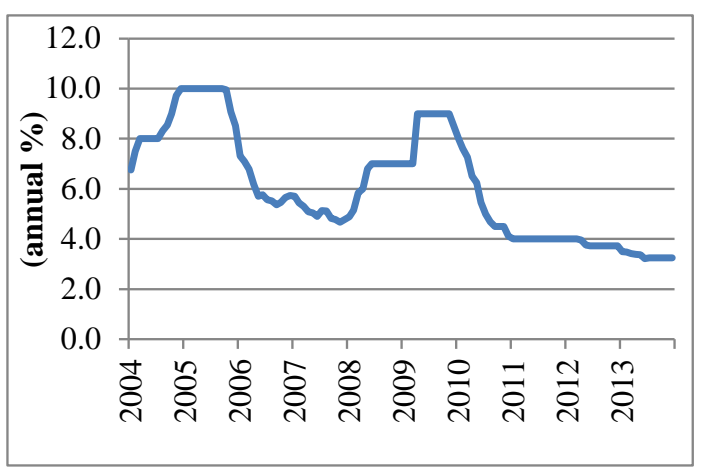

Figure 4. CB bills rate (key policy rate) Source: NBRM

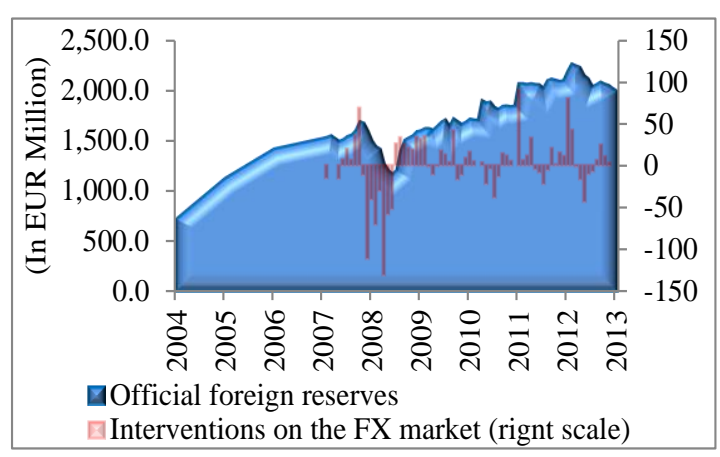

Figure 3. Official reserve assets Source: NBRM

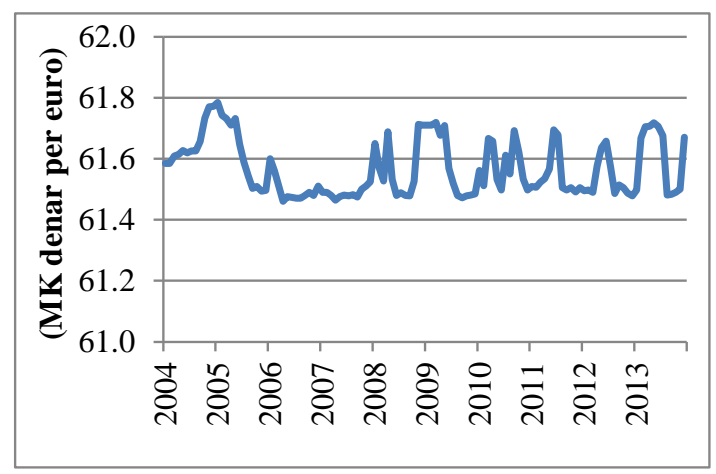

Figure 5. Exchange rate MKD/EUR Source: NBRM

The outbreak of the global economic and financial crisis initially had a limited influence on stability in Macedonia, mainly due to a lower degree of integration of the Macedonian financial sector to the global markets. For these reasons, NBRM did not respond by easing monetary conditions immediately. However, prolonged uncertainty in the external environment and reduced economic activity of the most important trading partners had negative impact on the Macedonian economy that is characterized by high foreign trade, especially with the countries from the European Union. After the bankruptcy of the investment house Lehman Brothers, risk perceptions of investors increased, leading to a significant reduction in transactions volume and to the lack of liquidity in international markets. These trends were reflected on the markets in the region by increasing external imbalances, the demand for foreign exchange has climbed and the pressures for depreciation of the domestic currency surged. To overcome these developments, the NBRM responded with significant interventions by selling foreign exchange and providing sufficient foreign currency liquidity to markets (Figure 3). At the same 
time, unlike the central banks of developed economies, which reacted towards monetary easing, the NBRM increased the interest rate on the main monetary policy instrument. Monetary tightening contributed the balance of payments pressures to be reduced and the foreign exchange reserves to be maintained around the adequate level, which helped keeping the external sustainability and the peg (Figure 5).

In the next period, economic activity declined and inflation expectations have been stabilized, that imposed a lessening the $\mathrm{CB}$ bill rate. However, due to the potential risks of re-deterioration of external imbalances in the country, the reaction of the NBRM towards loosening of the monetary conditions was gradual (Figure 4).

While the monetary policy was not limited with interest rates close to zero lower bound, prolonged duration of the global economic and financial crisis led the NBRM to join central banks that applied unconventional measures. Taking into account the potential risks of re-deterioration of external imbalances and inflationary pressures, as well as with aim to provide support for other purposes, including credit growth, several changes were made in the reserve requirements. Namely, the reserve requirement was reduced by the amount of newly granted loans and investments in debt securities issued by net exporters and/or by non-financial companies that use these funds for financing projects for domestic electricity production. The main purpose of this temporary measure was to provide support to systematically important sectors of the economy in terms of the balance of payments flows and the foreign exchange market movements. Also, the reserve requirement ratio on the liabilities in domestic currency was lowered, simultaneously tightening reserve requirement ratio on foreign exchange liabilities. Additionally, the banks' long-term liabilities to non residents are excluded, as $0 \%$ reserve requirement was prescribed. This measure achieved dual effect: first, it provided stimulus to local currency deposit growth in and second, encouraged the longer-term capital funding of domestic banks.

Throughout the crisis, the banking sector remained sound, relying on domestic sources of funding, preserving strong capital adequacy and liquidity ratios, and keeping non-performing loans in check with adequate provisioning.

\section{The Impact of the Crisis on the Independence of Central Banks and their Operational Efficiency}

The issue of the main challenges of the contemporary central banking, especially during the current global economic and financial crisis has triggered numerous debates and discussions throughout the world, attracting the attention of both, the practitioners (central bankers) and the academics. Many central banks, especially from developed countries played critical role during the crisis in maintaining financial stability and supporting the macroeconomic policy. Hence, these two goals got specific weight and importance in the central bank regulations, certainly without jeopardizing the main goal - maintenance price stability. This is actually very important trend and challenge for the central banking in the future. In order to accomplish these goals, central banks should have very high level of independence, transparency and accountability which are certainly main preconditions for their efficient management and governance.

\subsection{Analysis of the legal independence of the central banks}

The significance and the importance of the central bank independence are reflected in the fact that it is the necessary precondition for accomplishing their legally determined objectives, tasks and functions. In order to determine the level of central bank independence and to examine the basic relations between the independence and the main macroeconomic indicators, it is necessary to predetermine independence criteria. Independence criteria are the basis for construction of the main analytical set of instruments for measuring central bank independence. Namely, the legal independence of the central bank could be viewed from several aspects:

- Functional independence, which implies independent determination of the objectives and tasks, i.e. primary objective - maintaining price stability, has to be unambiguously expressed and defined in the central bank law;

- Institutional independence, which implies absence of external influence in the decision-making processes;

- Personal independence, which is observed through elimination of political pressure on the decision-making bodies of the central bank;

- Financial independence, which is observed through autonomy in the disposal and use of funds.

The independence of the central banks does not exclude their accountability and obligation for being transparent in their operations. They should go together, "hand by hand".

As previously explained, in order to measure the central bank independence, it is necessary to determine appropriate criteria for quantification of the level of independence. Therefore, so-called legal indexes are used for measuring of the central bank legal independence. The most detailed indexes are determined by Cukierman/Webb/Neyapti in 1992. These authors take into account 16 characteristics (variables) of central bank independence divided into four groups of variables (issues):

- Chief executive officer in the central bank (governor); 
- Formulation of monetary policy;

- Objectives of the central bank and

- Central bank lending.

Also, very frequently "Modified Cukierman index" is used, or Cukierman LVAW index, which takes into account 18 characteristics (variables), divided into five groups:

- Central bank board;

- Central bank objectives;

- Policy formulation;

- Central bank lending and

- Accountability.

Each of the variables has been disaggregated into several individual variables. Each individual variable has a numerical coding from 0 (lowest level of independence), to 1 (highest level of independence).

In the table below, using the Cukierman LVAW index, we made a comparison of the level of independence of the NBRM with the independence of central banks of several selected EU countries - potential EMU members: Czech Republic, Hungary, Poland and Croatia.

\begin{tabular}{|c|c|c|c|c|c|}
\hline & 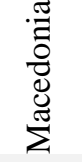 & 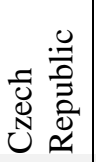 & 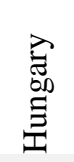 & $\begin{array}{l}\vec{\Xi} \\
\text { 잉 }\end{array}$ & 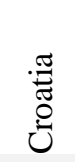 \\
\hline \multicolumn{6}{|l|}{ 1. Central Bank Chief Executive Officer } \\
\hline Term of office of CEO & 0.75 & 0.75 & 0.75 & 0.75 & 0.75 \\
\hline Who appoints the CEO & 0.5 & 0.5 & 0.25 & 0.5 & 0.5 \\
\hline Provisions for dismissal of $\mathrm{CEO}$ & 0.83 & 0.83 & 0.83 & 0.83 & 0.83 \\
\hline CEO allowed to hold another office in government & 1 & 1 & 0.5 & 1 & 1 \\
\hline \multicolumn{6}{|l|}{ 2. Central Bank objectives } \\
\hline Central Bank objectives & 1 & 1 & 1 & 1 & 1 \\
\hline \multicolumn{6}{|l|}{ 3. Policy formulation } \\
\hline Who formulates monetary policy & 1 & 1 & 1 & 1 & 1 \\
\hline Government directives and resolution of conflicts & 1 & 1 & 1 & 1 & 1 \\
\hline Central Bank given active role in formulation of government's budget & 0 & 0 & 1 & 1 & 0 \\
\hline \multicolumn{6}{|l|}{ 4. Central Bank lending } \\
\hline Limitations on advances & 1 & 1 & 1 & 1 & 1 \\
\hline Limitations on securitized lending & 1 & 1 & 1 & 1 & 1 \\
\hline Who decides control of terms of lending to government & n.a. & n.a. & 0.66 & n.a & 1 \\
\hline Beneficiaries of Central Bank lending & 1 & n.a. & 1 & n.a & 1 \\
\hline Type of limits when they exist & n.a & n.a. & n.a. & n.a & 1 \\
\hline Maturity of loans & 1 & n.a. & 1 & n.a & 1 \\
\hline Restrictions on interest rates & n.a. & n.a. & 1 & n.a & 1 \\
\hline Prohibition on Central Bank lending to Government on primary market & 1 & 1 & 1 & n.a & 1 \\
\hline TOTAL: & 0.9 & 0.9 & 0.89 & 0.95 & 0.9 \\
\hline
\end{tabular}

Table 1. Comparison of the level of legal independence of a group of selected Central Banks

The Table 1. shows that the level of independence of the NBRM measured by the Cukierman LVAW index (0.90) is equal with the level of the Czech National Bank and with the Croatian National Bank. It is higher than the level of the Hungarian National Bank (0.89) and lower than the National Bank of Poland (0.95). Generally speaking, the NBRM, Croatian National Bank and the Czech National Bank should have more active role in formulation of government's budget. The Hungarian National Bank should be more autonomous from the executive authority in the process of appointment of its governor.

What is very important, considering the central bank independence within the context of the great financial crisis, is that all analyzed central banks have accommodated their statutes in order to respond to the crisis i.e. stipulating the financial stability together with the price stability as a main central bank goal.

As explained earlier, during the crisis the central banks have been overburdened by the prolonged monetary policy accommodation and heavily posed by longer-term risks to their reputation and credibility. The gap between what central banks are expected to deliver and what they actually can deliver became too wide. Also, the confidence in their ability to fulfill their mandates for price and financial stability can be undermined by this gap and at the same time may have consequences for their independence and the operational efficiency. Such 
considerations may create pressure on central banks to keep monetary policy too lax for too long. It is obvious that the effectiveness of central bank policymaking in the current environment is seriously threatened.

\subsection{Operational efficiency of central banks}

Nationwide, there is no institution that can be a benchmark for comparison of the central bank efficiency, as it is the case in the private sector. Hence, in order to determine the level of efficiency of the central bank we need to make a comparison with other central banks worldwide. To make a proper comparison, it is necessary to take into account several elements: the influence of executive authorities, i.e. the level of central bank independence; the size of the country, its population, the size of GDP, and so on.

By applying these two general principles, the definition of operational efficiency of the central bank could be derived from an analysis of the use of the central bank resources or inputs (labor and capital) in performing its legally entrusted functions, to achieve its objective or output, compared with other central banks worldwide.

Central banks with high level of operational independence under the law actually have higher discretion in the monetary policy implementation. The question is how central banks use this discretionary power. In practice, two types of inefficiencies of central banks can be distinguished: legal inefficiency and managerial inefficiency. Legal inefficiency arises from the inadequate level of operational independence, which the central bank has obtained according to the legislation in the sense that the central bank is entrusted a number of functions that are not directly related to achieving its primary objective - price stability, which in turn create inefficiency in its operations. Managerial inefficiency occurs when the central bank shows inefficiency in carrying out the functions that are directly related to the achievement of the primary objective. An example of this inefficiency of the central bank is when there are too many employees engaged in the core functions accomplishment due to the lack of will among the management to reduce the excessive employment.

In this regard it is important to emphasize the significance of two issues:

1. Outsourcing, i.e. use of services of external entities in the field of administrative functions, information technology etc.

2. Change management. This includes: risk management; proper and cost-efficient distribution of inputs, limiting the scope of the changes only in the field of the core activities of the central bank, etc.

To measure the operational efficiency of the central banks, a number of basic indices have been designed. These indices may be used as a basis for improving the efficiency of central banks by adopting good practices of those central banks that are deemed highly operationally efficient. Further in the paper we will go through the main features of several basic indices for measuring central banks efficiency.

Hanke index, or the central bank staff efficiency index, uses the output to input ratio and has the following form: number of employees / gross national product In this formulation, the number of employees in the central bank, i.e. the resources used by the central bank is the input, while the gross national product, i.e. the size of the economy whose normal functioning is the main goal of the central bank by providing price stability, is the output. This index provides a rough assessment of staff efficiency in the central bank. Lower value of the Hanker index indicates greater efficiency of the central bank and vice versa.

Morgan Stanley index shows how many employees are engaged in the central bank on 100,000 inhabitants. This index may be expressed as: (number of employees in the central bank / size of population) * 100,000. As in the Hanker index, the number of employees in the central bank is the input in this formulation, while the total population in the country is the output.

Mendzela index is also a central bank staff efficiency index. It uses as output the two previously mentioned indicators, the total population and the gross national product, but as input, rather than the number of employees, it uses the operational costs. So far, this index has been used for operational efficiency analysis of the central banks of OECD countries.

Vaubel index may be used for the central bank operational efficiency measurement, although it is not specified in the economic literature. This index may be derived using the following formula:

$\ln \mathrm{L}=\ln \mathrm{b} 0+\mathrm{b} 1 \ln \mathrm{M}+\mathrm{b} 2 \ln \mathrm{N}+\mathrm{b} 3 \ln \mathrm{A}+\mathrm{b} 4 \mathrm{~S} \ln \mathrm{M}+\mathrm{b} 5 \operatorname{S} \ln \mathrm{N}+\mathrm{b} 6 \mathrm{~S} \ln \mathrm{A}+\mathrm{b} 7 \mathrm{ClnM}+\mathrm{b} 8 \mathrm{C} \ln \mathrm{N}+\mathrm{b} 9 \mathrm{C} \ln \mathrm{A}+\mathrm{b} 10 \ln \mathrm{I}$ $+\mathrm{b} 11 \ln \mathrm{E}+\mathrm{b} 12 \ln \mathrm{Y}+\mathrm{v}$

Where:

$\mathrm{L}=$ number of employees in the central bank

$\mathrm{M}=$ money supply $\mathrm{M} 1$

$\mathrm{N}=$ number of population in the country (in millions)

$\mathrm{A}=$ geographic area of the country 
$\mathrm{S}=$ grade 1 is given if the central bank is responsible for supervision of banks, 0.5 if the central bank performs this function jointly with another institution and 0 if the central bank does not perform this function

$\mathrm{C}=$ grade 1 is given if the country belongs to the group of countries "Conecon" and 0 if it does not belong to that group of countries

$\mathrm{I}=$ index of central bank independence

$\mathrm{E}=$ dummy variable that has the value 2.72 if the exchange rate is pegged and 1 if there is another regime

$\mathrm{Y}=$ GNP or GDP per capita

The input, number of employees in the central bank, is modeled as a function of its output, which is approximated with different variables: money supply, number of total population in the country, geographic size of the country, etc.

\subsection{Pre/post crisis measuring the operational efficiency of a group of selected central banks}

We have previously noted that several basic indices have been constructed for measuring the operational efficiency of the central banks. These indices can be used as a basis for improving the efficiency of central banks by adopting the good practices of those central banks that are deemed highly operationally efficient. To measure the operational efficiency of the NBRM, we will use the Hanke index and the Morgan Stanley index on several selected countries. The comparison is made with the countries that have passed the transitional process as Macedonia.

\begin{tabular}{|c|c|c|c|}
\hline Country & $\begin{array}{r}\text { GNP in billion US dollars } \\
\text { for } 2012\end{array}$ & $\begin{array}{l}\text { Number of employees in } \\
\text { the central bank for } 2012\end{array}$ & $\begin{array}{r}\text { Hanke Index (Staff per } \\
\text { Billion US dollars) }\end{array}$ \\
\hline Macedonia & 22 & 433 & 20.06 \\
\hline Armenia & 18 & 775 & 43.13 \\
\hline Montenegro & 7 & 327 & 45.67 \\
\hline Lithuania & 62 & 681 & 11.06 \\
\hline Serbia & 79 & 2,136 & 27.12 \\
\hline Latvia & 35 & 537 & 15.39 \\
\hline Ukraine & 329 & 1,512 & 4.59 \\
\hline Bosnia and Herzegovina & 32 & 354 & 11.21 \\
\hline Hungary & 196 & 584 & 2.99 \\
\hline Romania & 267 & 2 & 0.01 \\
\hline Moldova & 12 & 466 & 38.83 \\
\hline Georgia & 25 & 305 & 12.43 \\
\hline Bulgaria & 101 & 860 & 8.51 \\
\hline Croatia & 79 & 636 & 8.02 \\
\hline Albania & 25 & 521 & 20.58 \\
\hline Czech Republic & 285 & 1,398 & 4.91 \\
\hline Belarus & 142 & 3,228 & 22.76 \\
\hline Poland & 771 & 3,642 & 4.72 \\
\hline Euro system & 11,258 & 47,567 & 4.23 \\
\hline United States & 15,080 & 20,544 & 1.36 \\
\hline United Kingdom & 2,288 & 2164 & 0.95 \\
\hline Japan & 4,444 & 4,668 & 1.05 \\
\hline
\end{tabular}

Table 2. Nominal GNP, number of Central Bank employees and Hanke index Source: Central bank web sites

The gross national product of Macedonia as of 31.12.2012 amounted to USD 21.59 billion, and the number of employees in the NBRM at the end of 2012 was 433. The resulting index for the NBRM according to Hanke is 20.06. This shows that one billion US Dollars GNP accounts for 20.06 employees of the central bank. The Table 2, shows the rank of the NBRM regarding the operational efficiency, measured by the Hanke index, compared with the calculated indexes for operational efficiency of the central banks from a selected group of countries. The data lead to the following conclusion: out of the total number of 18 countries analyzed, Macedonia is ranked 12th. NBRM has greater operational efficiency than the following countries: Montenegro (45.67); Armenia (43.13); Moldova (38.83); Serbia (27.12); Belarus (22.76) and Albania (20.58). On the other hand, Macedonia has a lower operational efficiency than the following countries: Hungary (2.99); Ukraine (4.59); Poland (4.72); Czech Republic (4.91); Romania (6.74); Croatia (8.02); Bulgaria (8.51); Lithuania (11.06); Bosnia and Herzegovina (11.21); Georgia (12.43); Latvia (15.39).

For comparison, the operational efficiency of the Euro system is 4.23 (total GNP realized in the Euro system at the end of 2012 amounted to US Dollars 11,258,31 billion, while the total number of employees in the central banks of the Euro system is 47.567), compared with USA $(1,36)$, UK $(0,95)$ and Japan $(1,05)$. 
Below, we will determine the level of operational efficiency of the NBRM by using Morgan - Stanely index. The total population of Macedonia in 2012 amounted to 2,062,294 inhabitants, and the number of employees in the NBRM at the end of 2012, as we have already mentioned, was 433. So we obtain the following ratio: (433 / $2,062,294) * 100.000=20.99$.

Presented below is Table 3, which contains data for the Morgan Stanley index and its elements for the same group of countries, analyzed by using the Hanke index. The data contained in the Table 3. lead to the following conclusion: the NBRM has greater operational efficiency (lower value of the index) than the central banks of the following countries: Montenegro (49.74); Belarus (33.47); Serbia (29.35); Armenia (26.09) and Latvia (24.50); On the other hand, the NBRM has lower operational efficiency (higher value of the index) than the following transition countries: Ukraine (3.37); Hungary (5.86); Georgia (6.67); Romania (8.24); Bosnia and Herzegovina (9.13); Poland (9.48); Bulgaria (12.22); Moldova (12.74); Czech Republic (13.74); Croatia (14.20); Albania (17.35); and Lithuania (19.31).

So, out of 18 analyzed countries in transition, the NBRM is ranked 13th. This index, also as the Hanker index, provides a rough assessment of the operational efficiency of the central bank, but it is remarkable that in the analysis of a group of 18 countries using the two indexes, NBRM is ranked almost the same (12th and 13th). Of course, the precise determination of the operational efficiency requires other elements to be taken into account, both quantitative and qualitative.

The level of the operational efficiency of the Euro system using Morgan Stanly index is 14.29, USA (6.55), UK (3.43) and Japan (3.66).

\begin{tabular}{|l|r|r|r|}
\hline Country & Population & $\begin{array}{r}\text { Number of employees } \\
\text { in the central bank }\end{array}$ & Morgan Stanley index \\
Macedonia & $2,062,294$ & 433 & 20.99 \\
Armenia & $2,970,495$ & 775 & 26.09 \\
Montenegro & 657,394 & 327 & 49.74 \\
Lithuania & $3,525,761$ & 681 & 19.31 \\
Serbia & $7,276,604$ & 2,136 & 29.35 \\
Latvia & $2,191,580$ & 537 & 24.50 \\
Ukraine & $44,854,065$ & 3.37 \\
Bosnia and Herzegovina & $3,879,296$ & 1,512 & 9.13 \\
Hungary & $9,958,453$ & 354 & 5.86 \\
Romania & $21,848,504$ & 584 & 8.24 \\
Moldova & $3,656,843$ & 1,800 & 12.74 \\
Georgia & $4,570,934$ & 466 & 6.67 \\
Bulgaria & $7,037,935$ & 305 & 12.22 \\
Croatia & $4,480,043$ & 860 & 14.20 \\
Albania & $3,002,859$ & 636 & 17.35 \\
Czech Republic & $10,177,300$ & 521 & 13.74 \\
Belarus & $9,643,566$ & 1,398 & 33.47 \\
Poland & $38,415,284$ & 3,228 & 9.48 \\
\hline Euro system & $332,975,153$ & 3,642 & 14.29 \\
United States & $313,847,465$ & 47,567 & 6.55 \\
United Kingdom & $63,047,162$ & 20,544 & 3.43 \\
Japan & $127,368,088$ & 2,164 & 3.66 \\
\hline
\end{tabular}

Table 3. Morgan Stanley index - number of employees in the Central Bank against the number of inhabitants Source: The Morgan Stanley "Central Bank Directory 2010"

The Table 4 presents the changes in the staff number of the analyzed central banks from 2007-2012. Nine central banks, out of eighteen reduced the number of their employees from 2007 to 2012. Also, the Euro system reduced the number of employees for $3.13 \%$. This was a central banks' reaction to the negative consequences of the crisis and their strong involvement in keeping the financial stability. This new role of the central banks has, of course, very negative impact of their operational efficiency. Hence, most of the analyzed central banks made appropriate reduction of their staff.

Unfortunately, eight of analyzed central banks have increased the number of their staff. Some of them very remarkably: Belarus (294.14\%); Poland (83.57\%) and Ukraine (47.22\%). These countries will face high decrease of their operational efficiency and have to make additional extra efforts in the future.

In the analyzed period, the NBRM has increased the number of the employees for $8.25 \%$. The main increase is done from 2007-2010. In 2011 and 2012 the number of employees decreased. 


\begin{tabular}{|l|r|r|r|}
\hline Country & 2007 & 2012 & Change (\%) \\
Macedonia & 400 & 433 & 8.25 \\
Armenia & 620 & 775 & 25.00 \\
Montenegro & 350 & 327 & -6.57 \\
Lithuania & 851 & 681 & -19.98 \\
Serbia & 2,521 & -15.27 \\
Latvia & 629 & 2,136 & -14.63 \\
Ukraine & 1,027 & 537 & 47.22 \\
Bosnia and Herzegovina & 315 & 1,512 & 12.38 \\
Hungary & 690 & 354 & -15.36 \\
Romania & 1,812 & 584 & -0.66 \\
Moldova & 445 & 1,800 & 4.72 \\
Georgia & 558 & 466 & -45.34 \\
Bulgaria & 928 & 305 & -7.33 \\
Croatia & 594 & 860 & 7.07 \\
Albania & 416 & 636 & 25.24 \\
Czech Republic & 1,480 & 521 & -5.54 \\
Belarus & 819 & 1,398 & 294.14 \\
Poland & 1,984 & 3,228 & 83.57 \\
\hline Euro system & 49,103 & 3,642 & -3.13 \\
United States & 21,521 & 47,567 & -4.54 \\
United Kingdom & 1,789 & 20,544 & 20.96 \\
Japan & 4,912 & 2,164 & -4.97 \\
\hline
\end{tabular}

Table. 4 Changes in Staff Numbers 2007-2012 Source: The Morgan Stanley "Central Bank Directory 2010"

We have previously pointed out that the operational efficiency of the central bank is on a high level if the central bank performs only those functions that are directly related to its primary objective - price stability. An imperative for the central bank is that the core functions have to be performed in accordance with best international practices and international standards. Does the NBRM perform additional functions, beside its core functions, that are not directly related to the primary objective? In the period from 2006 to the end of 2010, the NBRM conducted additional function - custodian of pension funds. Although the function of custodian was granted for a relatively short period of 5 years (according to the Law on the Fully Funded Pension Insurance), it was clear that its implementation is not directly related with the achievement of the primary goal and that will reduce the operational efficiency of the NBRM, as it takes effort, time and capital. Analyses show that, besides the NBRM, worldwide only the central bank of Chile performs this function. Certainly, increasing the level of operational efficiency of the NBRM is not an aim only for the central bank, but also for the society as a whole. Therefore, the joint commitment of the central bank and the other relevant factors in the country can contribute to the harmonization of the regulations for the central bank in this domain with the European standards, and make a step forward in bringing Macedonia closer to the European Union.

On the other hand, the purchase of the rare and the original coins from the territory of Macedonia, in terms of the accomplishment of the primary goal is not a core function of the NBRM. The question is whether the central bank should carry out this function. In this regard it should be emphasized that all central banks in the world, almost without exception, perform this function. Namely, the purchase of rare and the original coins incorporate the historical and educational point of monetary finance and it is an assessment of many experts that it should be carried out by the central bank.

In this regard it should be emphasized that an increasing number of central banks worldwide follow the trend of outsourcing of their functions that are not directly related to their primary objective or belong to the category of so-called support functions. Several central banks even entrust some of their functions which are not directly related to the primary objective, such as: human resources management, maintenance of the information system, etc. to specialized agencies outside of the central bank. However, the analyses that should be made in this regard will show whether the NBRM should follow this trend, viewed in a longer run. Here, besides the financial aspect, it is certainly important to bear in mind that outsourcing has to be cost effective and from qualitative aspect, that means to provide better and more efficient accomplishment of the central bank functions.

\section{Conclusion}

During the financial crisis, the central banks around the world activated a wide range of unconventional policy measures that were important element of their strategies for rescue of the financial system, for stabilizing the markets and encouraging the economic growth. These policies have changed the character and nature of the independence of the central banks. The pressures for overloading of the monetary policy with multiple goals, 
although these goals are declared as temporary, given the potential risks for price stability, may adversely affect the credibility of the central banks. Furthermore, the measures taken during the crisis had a negative impact on the operational efficiency of the central banks, which contributed to a reduction of the number of employees in a large part of the analyzed central banks.

Looking further ahead, with gradual smoothing of the effects of the economic and financial crisis, central banks are at a crossroads: where should be directed to, i.e. what should be the role of unconventional monetary policy tools in post-crisis operational frameworks?

In our view, prolonged use of unconventional measures may cause problems in achieving the core central bank functions. The operational framework of the central bank should be primarily aimed at maintaining price stability and control over the short-term interest rates. This would provide enough room for reaction in extraordinary circumstances, which ensures the potential external or internal economic shocks to be easily overcome.

During the crisis, the monetary policy of the National Bank retained the concept of maintaining price stability and the stability of the exchange rate as the main priorities. However, faced with a decline in economic activity, the National Bank was triggered to introduce new measures and instruments to spur the revival of credit growth and to support certain systemic important sectors. Although these measures are unconventional because their implementations go beyond the usual range of the monetary policy, by maintaining price stability as the main priority and in coordination with other economic policies, the National bank contributed the internal and external economic shocks to be overcome easier and the macroeconomic stability to be maintained, without jeopardizing its independence.

\section{References}

- $\quad$ Ben S. Bernanke, February 18.2009, "Federal Reserve Policies to Ease Credit and Their Implications for the Fed's Balance Sheet", prepared as a speech at the National Press Club, Washington D.C.

- BIS, December 2013, "Is monetary policy overburdened?” BIS Working Papers No 435.

- Ceccheti S.G., Flores-Lagune A \& Krause S, 2006 "Has Monetary Policy Become more Efficient, a Cross Country Analysis", Economic Journal, vol.116, 408-433.

- ECB, November 2013, "Financial Stability Review" http://www.ecb.europa.eu/pub/pdf/other/financialstabilityreview201311en.pdf

- IMF, April 18, 2013, "Unconventional Monetary Policies - Recent Experience and Prospects",

- Jaime Caruana, 2013. "The Changing Nature of Central Bank Independence", in Proceedings of Bank of Mexico international conference, 14-15 October 2013, "Central bank independence - Progress and challenges".

- Jean-Claude Trichet, 2012. "Unconventional Monetary Policy Measures", in Proceedings of IJCB conference, March 23-24, 2012, "Central Banking: Before, during and after the crisis".

- John C. Williams, 2011. "Unconventional Monetary Policy: Lessons from the Past Three Years", in Proceedings of Swiss National Bank Research Conference, September 23, 2011.

- Loretta J. Mester, 2003. “Applying Efficiency Measurement Techniques to Central Banks”, Federal Reserve Bank of Philadelphia and Finance Department, the Wharton School, University of Pennsylvania.

- Manuel Sanchez. 2013. “Central Bank Independence: Progress and Challenges”, in Proceedings of the International Conference, Mexico City, October 15, 2013, p. 3.

- Marek Belka, 2013. "Central Bank Independence: Progress and Challenges”, in Proceedings of the International Conference, Mexico City, October 15, 2013, p. 3.

- National Bank of Republic of Macedonia http://www.nbrm.mk/

- Patricia S. Pollard, 1999. "Central Bank Independence and Economic Performance", Federal Reserve Bank of St. Louis.

- Ricardo Davico and Brian John Goldsmith, December, 2012. "Ballooning Balance Sheets", Finance \& Development.

- Sharon Kozicki, Eric Santor and Lena Suchanek, 2011, "Unconventional Monetary Policy: The International Experience with Central Bank Asset Purchases", Bank of Canada Review.

- Vern McKinley and King Banaian, 2003. "Central Banks Operational Efficiency: meaning and measurement", Bearing Point, Inc. 